\title{
Elementary knowledge about epilepsy among the patients, their family, and common people
}

Amin Husni

\begin{abstract}
Abstrak
Diasumsikan bahwa pendidikan dan penerangan kesehatan telah dilakukan dan diberikan melalui wahana pelayanan kesehatan serta media massa, namun nampaknya di kalangan penderita dan masyarakat awam tingkat pengetahuan mereka tentang epilepsi kurang memadai. Dalam penelitian ini telah dilakukan wawancara terhadap 127 penderita epilepsi di klinik rawat jalan Rumah Sakit Dr. Kariadi Semarang, 95 orang keluarga pasien, dan 95 orang awam untuk mengungkap pengetahuan mereka tentang organ utama tubuh yang terganggu, etiologi, gejala-gejala dan tanda-tanda, dan faktor pemicu bangkitnya kejang berulang pada epilepsi. Jawaban-jawaban para responden dicatat secara verbatim, kemudian dianalisis dengan mencocokkan jawabannya dengan jawaban yang benar menurut literatur. Hasil analisis didapatkan pengetahuan yang jelek dan kurang tentang organ tubuh yang terganggu, etiologi, gejala-gejala dan tandatanda, dan faktor pemicu bangkitnya kejang berulang pada epilepsi pada kelompok pasien, keluarga pasien, dan orang awam. Pada ketiga kelompok tersebut tidak terdapat perbedaan bermakna tingkat pengetahuan mengenai epilepsi. Tingkat pengetahuan pasien terendah dibanding dua kelompok yang lain. Tingkat pendidikan tidak mempengaruhi tingkat pengetahuan responden. Temuan tersebut menggambarkan kurang memadainya komunikasi antar dokter dan pasien pada wahana pelayanan kesehatan serta pendidikan kesehatan masyarakat tentang epilepsi yang diterima oleh keluarga pasien dan orang awam. (Med J Indones 2003; 12: 29-39)
\end{abstract}

\begin{abstract}
It is assumed that health education has been done and health information has been given through health service institutions and mass media, but it seems that the patients as well as common people have insufficient knowledge about epilepsy. Interviews had been carried out upon 127 epilepsy patients in out patient clinic Dr. Kariadi Hospital Semarang, 95 patients' family, and 95 common people to explore their knowledge on the main disturbed organ, etiology, symptoms and signs, and trigger factors of repeating seizure in epilepsy. The respondents' answers were recorded verbatim, and analyzed by matching to the right answers according to references. Bad and insufficient knowledge on the main organ disturbed in epilepsy, etiology, symptoms and signs, and trigger factors for repeated seizure was founded among the epilepsy patients, their family, and common people. There were no significant differences of the level of knowledge among the three groups of respondents. The patients' knowledge was the worst, compared to the others. The level of education of the respondents did not influence their level of knowledge. In conclusion, this study reflects an insufficient communication between doctors and the patients in the health service institution, and an insufficient public health education about epilepsy received by the patients' family and common people. (Med J Indones 2003; 12: 29-39)
\end{abstract}

Keywords: epilepsy, knowledge, patients, common people

Epilepsy is still being a problem in Indonesia. It is not only because of medical matters, but also the people's ignorance and misperception about the syndrome.

Many efforts have been conducted to educate people about epilepsy. ${ }^{1}$ The Indonesian Neurological Association has developed a national consensus on general guidance for coping the epilepsy problems. ${ }^{2}$

Department of Anatomi-Neurology, Faculty of Medicine, University of Diponegoro, Semarang, Indonesia
The consensus contains guidance for medical, psychosocial, and suggestion for legal matters, which is hopefully used by medical practitioners in public health services. Besides the education for the medical practitioners, who will educate the patients and or common people, education for the common people had been delivered through mass media. In this case, the role of Perhimpunan Penanggulangan Epilepsi Indonesia (PERPEI: The Indonesian League Against Epilepsy) is very important.

Even though the education has been done and information has been given, it seems that among 
common people, including patients, there is insufficient knowledge on epilepsy. ${ }^{1.3}$

This paper reports a study on elementary knowledge about epilepsy among the patients, their family, and common people. An analysis about the influence of respondents' level of education, to the knowledge of epilepsy, was also conducted.

\section{METHOD}

Open-ended questions were addressed to three groups of respondents:

1. Patients suffering from epilepsy, who were interviewed in the Neurology Outpatient Clinic of Dr. Kariadi Hospital during the visits.

2. The patients' relatives or caregivers, who have close relationship to the patients and had ever heard about epilepsy. The respondents were those who lived in the same house with the patients, and were interviewed in the Neurology Outpatient Clinic of Dr. Kariadi Hospital during the patient's visits, and or home visits by a staff of Department of Neurology.

3. Common people, who has no relationship to the patients, and stays far away from the patients' residence (around community Health Center in Mejobo, Kudus, $50 \mathrm{~km}$ away from Dr. Kariadi Hospital). The respondents were interviewed during home visits by a staff of Department of Neurology (the same person who performed the patients interviews). The respondent should ever hear the term of epilepsy even in local language.

All respondents gave their consent for interview.

The open-ended questions about elementary knowledge of epilepsy were prepared consisted of four questions:

a. What is the main disturbed organ in the body in epilepsy

b. What are the etiology of epilepsy

c. What are the symptoms and or signs of epilepsy

d. What are the trigger factors of repeated seizures in epilepsy?

To answer the questions, respondents were asked to mention briefly in their own words what they know about epilepsy, which were assumed as the right or wrong answers of the questions. The answers of the questions, except the question number one, might be more than one. The interviewer listed all the answers descriptively.

The interviewer then repeated the questions in another way or asking for clarification if there were any doubt on the answers. The answers was recorded verbatim, and then matched to the right answers.

Evaluation of the respondents' answers was executed as follow:

a) Question number 1: the right answer is the brain.

b) Question number 2: according to literatures, ${ }^{4.5 .6 .7}$ the etiologies of epilepsy are (1) idiopathic / unknown, (2) infection, (3) tumors, (4) congenital anomaly, (5) familial/hereditary, (6) vascular anomaly, (7) metabolic, and (8) head trauma.

c) Question number 3: ten symptoms and or signs of epilepsy ${ }^{4.5}$ are: (1) tonic / clonic / tonic-clonic seizure, (2) disturbed / undisturbed consciousness, (3) fall, (4) injured, (5) bitten tongue, (6) pale, (7) enuresis, (8) absance, (9) duration of insult in minutes, and (10) there is a post ictal syndrome (drowsiness, headache, pain, amnesia).

d) Question number 4: the trigger factors for a repeated seizure: ${ }^{4.5 .6 .7 .8}$ are (1) lack of sleep, (2) menstruation, (3) alcohol consumption, (4) hypoglycemia, (5) psychological stress, (6) fatigue, (7) hard noise, (8) bright light, (9) hard thinking, and (10) forget to consume oral anti epilepsy.

Regarding the referred information of the literatures mentioned above, the answers of respondents were a priori categorized as described in table 1 .

Analysis upon the collected answers was focused to explore main issues in this study:

(a) Level of knowledge on the four aspects of epilepsy among the three groups of respondents

(b) Comparison on the level of knowledge among the three groups

(c) The influence of education level to the respondent's knowledge on epilepsy?

SPSS 10.0 for Windows was executed for statistical analysis. Analysis Chi Square and Pearson-Chi Square tests were used. 
Table 1. Indicator and category of respondents' answers

\begin{tabular}{|c|c|c|c|}
\hline $\begin{array}{l}\text { Question } \\
\text { Number }\end{array}$ & The answers about & Category & Indicator \\
\hline 1 & $\begin{array}{l}\text { The main disturbed organ in the body } \\
\text { when epilepsy occurs }\end{array}$ & $\begin{array}{l}\text { 1. Right answer } \\
\text { 2. Wrong answer }\end{array}$ & $\begin{array}{l}\text { (1) The brain } \\
\text { (2) Other body organ }\end{array}$ \\
\hline 2 & The etiology of epilepsy & $\begin{array}{l}\text { 1. Excellent answer } \\
\text { 2. Good answer } \\
\text { 3. Fair answer } \\
\text { 4. Poor answer }\end{array}$ & $\begin{array}{l}\text { (1) 6-8 right answers } \\
\text { (2) 3-5 right answers } \\
\text { (3) 1-2 right answers } \\
\text { (4) No right answer }\end{array}$ \\
\hline 3 & The symptoms and or signs of epilepsy & $\begin{array}{l}\text { 1. Excellent answer } \\
\text { 2. Good answer } \\
\text { 3. Fair answer } \\
\text { 4. Poor answer }\end{array}$ & $\begin{array}{l}\text { (1) 8-10 right answers } \\
\text { (2) 4-7 right answers } \\
\text { (3) 1-3 right answers } \\
\text { (4) No right answer }\end{array}$ \\
\hline 4 & $\begin{array}{l}\text { The trigger factors of repeated seizure in } \\
\text { epilepsy }\end{array}$ & $\begin{array}{l}\text { 1. Excellent answer } \\
\text { 2. Good answer } \\
\text { 3. Fair answer } \\
\text { 4. Poor answer }\end{array}$ & $\begin{array}{l}\text { (1) 8-10 right answers } \\
\text { (2) 4-7 right answers } \\
\text { (3) 1-3 right answers } \\
\text { (4) No right answer }\end{array}$ \\
\hline
\end{tabular}

\section{RESULT}

During the period of September 1, 1999 up to May 31, 2000, as many as 317 respondents had been interviewed. Respondents of the patients and the patients' family group were collected as consecutive samples among the patients visited Out Patient Clinic of Dr. Kariadi hospital. The respondents was separated into 3 groups as follow:

a. Group I (patients) consisted of:

$(n=127)$

Grand mal epilepsy

116

Focal epilepsy

Temporal lobe epilepsy

Absance b. Group II (patients' family) consisted of: $(\mathrm{n}=95)$

Parent (mother/father) $\quad 74$

Spouse (wife/husband) $\quad 11$

Sibling 7

Children 3

c. Group III (common people) consisted of: $(\mathbf{n}=95)$

Government officers/army members $\quad 40$

Private employee 31

Labors $\quad 7$

Unemployment 31

\section{Characteristics of respondents}

The characteristics of the respondents are described in the table 2 . 
Table 2. The characteristic profile of the respondents

\begin{tabular}{|c|c|c|c|c|c|}
\hline \multirow[t]{2}{*}{ Characters } & $\begin{array}{c}\text { Group I } \\
\text { (patients) } \\
\mathbf{n = 1 2 7}\end{array}$ & $\begin{array}{c}\text { Group II } \\
\text { (patients' family) } \\
n=95\end{array}$ & $\begin{array}{c}\text { Group III } \\
\text { (common people) } \\
n=95\end{array}$ & Total & \multirow[t]{2}{*}{$\mathbf{p}$} \\
\hline & $(\%)$ & $(\%)$ & $(\%)$ & $(\%)$ & \\
\hline \multicolumn{6}{|l|}{ GENDER } \\
\hline 1. Male & 58.2 & 43.2 & 54.7 & 52.7 & 0.074 \\
\hline 2. Female & 41.7 & 56.8 & 45.3 & 47.3 & \\
\hline \multicolumn{6}{|l|}{ AGE (Years) } \\
\hline 1. Up to 19 & 30.7 & 3.2 & 2.1 & 13.9 & 0.001 \\
\hline 2. $20-29$ & 33.9 & 11.6 & 24.2 & 24.3 & \\
\hline 3. $30-39$ & 16.5 & 12.6 & 27.4 & 18.6 & \\
\hline 4. $40-49$ & 9.4 & 35.8 & 20.0 & 20.5 & \\
\hline 5. $50-59$ & 4.7 & 24.2 & 19.9 & 14.8 & \\
\hline 6. $>59$ & 4.7 & 12.6 & 7.4 & 7.9 & \\
\hline \multicolumn{6}{|l|}{ MARITAL } \\
\hline STATUS & & & & & 0.001 \\
\hline 1. Married & 34.6 & 76.8 & 60.0 & 54.9 & \\
\hline 2. Divorced & 2.4 & 13.7 & 7.4 & 7.3 & \\
\hline 3. Unmarried & 63.0 & 9.5 & 32.6 & 37.9 & \\
\hline \multicolumn{6}{|l|}{$\begin{array}{l}\text { EDUCATION } \\
\text { (School) }\end{array}$} \\
\hline 1. Elementary & 29.1 & 33.7 & 22.1 & 28.4 & 0.014 \\
\hline 2. Junior high & 24.4 & 31.6 & 22.1 & 25.9 & \\
\hline 3. Senior high & 33.1 & 26.3 & 31.6 & 30.6 & \\
\hline 4. Academy/ & 10.2 & $5 . .3$ & 23.2 & 12.6 & \\
\hline $\begin{array}{ll} & \text { University } \\
\text { 5. } & \text { Uneducated }\end{array}$ & 3.1 & 3.2 & 1.1 & 2.5 & \\
\hline
\end{tabular}

Data on table 2 showed that:

- In the Group I and Group III, the number of male patients was higher than female, but in general the sex showed no significant difference among the three groups

- Group I was dominated by unmarried subjects $(63 \%)$ while in the other two groups was dominated by married subjects.

- Most subjects in Group I was under 19 and 20-29 years old (30.70\% and $33.90 \%$ respectively). The age of respondents was significantly different among the subjects within the three groups.

- Most of the subjects in the groups were educated in any level of education. The level of education was significantly different among the three groups.

\section{Respondents' knowledge on four aspects of epilepsy}

The knowledge on four aspects of epilepsy in general, was described in table 3. 
Table 3. Distribution of the answers in a priory categories in general

\begin{tabular}{|c|c|c|c|}
\hline \multirow{2}{*}{ Question } & \multirow{2}{*}{$\begin{array}{c}\text { Category } \\
\text { of the answer }\end{array}$} & \multicolumn{2}{|c|}{ Frequency } \\
\hline & & (n) & $(\%)$ \\
\hline \multirow{2}{*}{$\begin{array}{l}\text { The main } \\
\text { disturbed organ } \\
\text { in the body } \\
\text { when epilepsy } \\
\text { occur }\end{array}$} & 1. Right answer & 77 & 24.3 \\
\hline & 2. Wrong answer & 240 & 75.7 \\
\hline \multirow{4}{*}{$\begin{array}{l}\text { The etiology of } \\
\text { epilepsy }\end{array}$} & 1. Excellent answer & 0 & 0.0 \\
\hline & 2. Good answer & 2 & 0.6 \\
\hline & 3. Fair answer & 160 & 50.5 \\
\hline & 4. Poor answer & 155 & 48.9 \\
\hline \multirow{4}{*}{$\begin{array}{l}\text { The symptoms } \\
\text { and or signs of } \\
\text { epilepsy }\end{array}$} & 1. Excellent answer & 0 & 0.0 \\
\hline & 2. Good answer & 13 & 4.1 \\
\hline & 3. Fair answer & 230 & 72.6 \\
\hline & 4. Poor answer & 74 & 23.3 \\
\hline \multirow{4}{*}{$\begin{array}{l}\text { The trigger } \\
\text { factors of } \\
\text { repeated seizure } \\
\text { in epilepsy }\end{array}$} & 1. Excellent answer & 0 & 0.0 \\
\hline & 2. Good answer & 8 & 2.5 \\
\hline & 3. Fair answer & 243 & 76.7 \\
\hline & 4. Poor answer & 66 & 20.8 \\
\hline
\end{tabular}

Data in table 3 shows that:

- The respondents in three groups showed a low level of knowledge on four aspects of epilepsy.

- Most of respondents (patients, the family, and common people) did not know the main disturbed organ in epilepsy.

- There were no excellent answers of the question of etiology, symptoms and signs, and the trigger factors of epilepsy among the three groups. Most the answers were the fair and poor categories, and only a small number of respondents gave good answers.

Based on the data in table 3 , then new posteriori categories have been created. The respondents' answers were redistributed into the new categories as presented in Table 4. Low-grade of the knowledge of the etiology, symptoms and signs, and the trigger factors of epilepsy (Table 3: a priori category) were distinguished in insufficient knowledge and bad knowledge categories.

Based on the data in table 4 it was found that:

- The respondents' knowledge of the etiology of epilepsy in general was almost equally distributed in the categories of insufficient and bad knowledge.
Table 4. Distribution of the answers in a posteriori category in general

\begin{tabular}{|c|c|c|}
\hline \multirow{2}{*}{$\begin{array}{l}\text { The new posteriori category of the } \\
\text { respondents' answers }\end{array}$} & \multicolumn{2}{|c|}{ Frequency } \\
\hline & (n) & $(\%)$ \\
\hline \multicolumn{3}{|l|}{$\begin{array}{l}\text { The knowledge of the main disturbed } \\
\text { organ in the body when epilepsy occur. }\end{array}$} \\
\hline 1. Right knowledge & 77 & 24.3 \\
\hline 2. Wrong knowledge & 240 & 75.7 \\
\hline \multicolumn{3}{|l|}{$\begin{array}{l}\text { The knowledge of the etiology of } \\
\text { epilepsy. }\end{array}$} \\
\hline 1. Insufficient knowledge & 162 & 51.1 \\
\hline 2. Bad knowledge & 155 & 48.9 \\
\hline \multicolumn{3}{|l|}{$\begin{array}{l}\text { The knowledge of the symptoms and } \\
\text { or signs of epilepsy. }\end{array}$} \\
\hline 1. Insufficient knowledge & 243 & 76.6 \\
\hline 2. Bad knowledge & 74 & 23.4 \\
\hline \multicolumn{3}{|l|}{$\begin{array}{l}\text { The knowledge of the trigger factors of } \\
\text { repeated seizure in epilepsy. }\end{array}$} \\
\hline 1. Insufficient knowledge & 251 & 79.2 \\
\hline 2. Bad knowledge & 66 & 20.8 \\
\hline
\end{tabular}

- Less than one-fourth respondent had bad knowledge on the symptoms and or signs of epilepsy and the trigger factors of repeated seizure, and the remaining subjects were categorized in insufficient knowledge. Both of categories (bad and insufficient) reflected the low grade of knowledge among the respondents.

\section{Respondents' knowledge of four aspects of epilepsy, by group}

Table 3 and Table 4 showed distribution of the respondents' answers in general. The table 5 showed distribution of the respondents' answers in the new category by group.

\section{The knowledge of the main disturbed organ in the body}

There was significant difference of knowledge about the main disturbed organ among the groups (p: 0.013). The number of right answer was smaller than the wrong one. It was surprising that the right answer was found smallest among the patients (group I) rather then the other groups (Group I). The highest number of the right answers was found among the patient family (Group II). 
Table 5. Distribution of the respondents' answer in the new category of the respondents' answers, by group

\begin{tabular}{|c|c|c|c|c|c|c|c|c|c|c|}
\hline \multirow[t]{2}{*}{ Group } & \multicolumn{2}{|c|}{$\begin{array}{c}\text { Knowledge of } \\
\text { organ }\end{array}$} & \multicolumn{2}{|c|}{$\begin{array}{c}\text { Knowledge of } \\
\text { etiology }\end{array}$} & \multicolumn{2}{|c|}{$\begin{array}{c}\text { Knowledge of } \\
\text { symptoms/signs }\end{array}$} & \multicolumn{2}{|c|}{$\begin{array}{l}\text { Knowledge of } \\
\text { trigger factors }\end{array}$} & \multicolumn{2}{|c|}{ Total } \\
\hline & {$[1]^{*}$} & {$[2]^{*}$} & {$[1]^{* * *}$} & {$[2]^{* * *}$} & {$[1]^{* *}$} & {$[2] * *$} & {$[1]^{* * *}$} & {$[2]^{* * *}$} & {$[1]^{* *}$} & {$[2]^{* *}$} \\
\hline I & 16.5 & 83.5 & 44.9 & 55.1 & 63.8 & 36.2 & 74.8 & 25.2 & 50.00 & 50.0 \\
\hline II & 33.7 & 66.3 & 50.5 & 49.5 & 84.2 & 15.8 & 87.4 & 12.6 & 63.9 & 36.1 \\
\hline III & 25.3 & 74.5 & 60.0 & 40.0 & 86.3 & 13.7 & 76.8 & 23.2 & 62.1 & 37.9 \\
\hline Total & 24.3 & 75.7 & 51.1 & 48.9 & 76.7 & 23.3 & 79.2 & 20.8 & 57.83 & 42.17 \\
\hline $\mathbf{p}$ & \multicolumn{2}{|c|}{0.013} & \multicolumn{2}{|c|}{0.083} & \multicolumn{2}{|c|}{0.001} & \multicolumn{2}{|c|}{0.059} & \multicolumn{2}{|c|}{0.001} \\
\hline
\end{tabular}

note:

Group I : the patients

Group II : the patients' family

Group III: common people

[1]*: Right knowledge

[2]*: Wrong knowledge
[1]**: Insufficient knowledge

[2]**: Bad knowledge
Wrong answers of the main disturbed organ in epilepsy included 'do not know', 'head', 'headache' were given by the patients; 'do not know', 'extremities', 'head', 'nerve' were given by the patients' family; 'do not know', 'head', and 'nerve disturbance' were given by the common people.

\section{The knowledge of the etiology of epilepsy}

There was no a significant difference on the knowledge about etiology among the groups $(\mathrm{p}=$ 0.083). Similar to the knowledge about the main organ, the smallest number of insufficient knowledge was found among the patients (Group I), while the biggest one was found among the common people (Group III).

Bad answers given by respondents of the three groups included 'do not know', 'fatigue', and 'psychological stress'.

\section{The knowledge about the symptoms and or signs of epilepsy and the trigger factors of repeated seizure}

Among the groups, most of the subjects showed insufficient knowledge about the symptoms and or signs of epilepsy and the trigger factors. There was significant difference about the knowledge of the symptoms and or signs of epilepsy on the knowledge $(p=0.001)$, but there was no significant difference about the trigger factors of repeated seizure $(\mathrm{p}=$ 0.059) among the groups. Again, the smallest number of insufficient knowledge was found among the patients' group (Group I).
'Do not know' and 'immediately happened' were the answer of most respondents which were categorized into bad knowledge of signs and or symptom. Bad knowledge about the trigger factors of repeated seizure included 'masuk angin' (Javanese idiom for a condition looked like influenza), 'unfit condition', 'crowded situation'; and the most answer was 'do not know'.

\section{Relationship between the knowledge of the four aspects of epilepsy and education level of respondents' education}

It is assumed that level of education will influence the respondents' level of knowledge on epilepsy. In this study, the relationship between the level of knowledge of the four aspects of epilepsy and the level of education has been analyzed. The respondents' answer of each group was distributed based on education and the level of knowledge, as shown in the Table $6 \mathrm{~A}, 6 \mathrm{~B}$, $6 \mathrm{C}$, and $6 \mathrm{D}$.

In every level of education, the proportion of the right knowledge about the main disturbed organ was smaller than wrong knowledge in all groups. Statistically, the knowledge showed no significant difference among the three group. In the common people group, all of the uneducated respondents gave wrong answers. In general, there was no significant difference of the knowledge about the main disturbed organ among the three groups of respondents (Table $6 \mathrm{~A})$.

In the group II (family) and group III (common people), the number of the insufficient knowledge 
about etiology was higher than bad knowledge. There was no significant difference of the level of knowledge on the etiology of epilepsy among the three groups (table 6B).

In general, the respondents' answers on the signs, symptoms and trigger factors of each group were mostly insufficient knowledge rather than bad one. There were no significant difference of the knowledge about the signs, and symptoms and trigger factors among the three groups of respondents. All of uneducated subjects had insufficient knowledge (table $6 \mathrm{C}$ and table 6D).

Table 6A. Distribution of respondents' answers (in percentage) about the knowledge of the main disturbed organ related to the level of education

\begin{tabular}{|c|c|c|c|c|c|c|c|c|}
\hline \multirow{3}{*}{$\begin{array}{l}\text { Level of education } \\
\quad \text { (school) }\end{array}$} & \multicolumn{6}{|c|}{ The knowledge of the main disturbed organ in the body } & \multirow{2}{*}{\multicolumn{2}{|c|}{ Total }} \\
\hline & \multicolumn{2}{|c|}{ Group I } & \multicolumn{2}{|c|}{ Group II } & \multicolumn{2}{|c|}{ Group III } & & \\
\hline & {$[1]^{*}$} & {$[2]^{*}$} & {$[1]^{*}$} & {$[2]^{*}$} & {$[1]^{*}$} & {$[2]^{*}$} & {$[1]^{*}$} & {$[2]^{*}$} \\
\hline Elementary & 21.6 & 78.4 & 34.4 & 65.6 & 49.2 & 51.7 & 31.1 & 68.9 \\
\hline Junior high & 9.7 & 90.3 & 33.3 & 66.7 & 23.8 & 76.2 & 22.0 & 78.0 \\
\hline Senior high & 14.3 & 84.7 & 36.0 & 64.0 & 23.3 & 76.7 & 22.7 & 77.3 \\
\hline Academy/University & 23.1 & 76.9 & 20.0 & 80.0 & 13.6 & 86.4 & 17.5 & 82.5 \\
\hline \multirow[t]{3}{*}{ Uneducated } & 25.0 & 75.0 & 33.3 & 66.7 & 0.0 & 100.0 & 25.0 & 75.0 \\
\hline & 16.5 & 83.5 & 33.7 & 66.3 & 25.3 & 74.7 & 24.3 & 75.7 \\
\hline & \multicolumn{2}{|c|}{0.642} & \multicolumn{2}{|c|}{0.975} & \multicolumn{2}{|c|}{0.245} & \multicolumn{2}{|c|}{0.453} \\
\hline
\end{tabular}

Table 6B. Distribution of respondents' answers (in percentage) about the knowledge of the etiology of epilepsy related to the level of education

\begin{tabular}{|c|c|c|c|c|c|c|c|c|}
\hline \multirow{3}{*}{$\begin{array}{l}\text { Level of education } \\
\quad \text { (school) }\end{array}$} & \multicolumn{6}{|c|}{ The knowledge of the etiology of epilepsy } & \multirow{2}{*}{\multicolumn{2}{|c|}{ Total }} \\
\hline & \multicolumn{2}{|c|}{ Group I } & \multicolumn{2}{|c|}{ Group II } & \multicolumn{2}{|c|}{ Group III } & & \\
\hline & {$[1]^{* *}$} & {$[2]^{* *}$} & {$[1] * *$} & {$[2]^{* *}$} & {$[1]^{* *}$} & {$[2]^{* *}$} & {$[1]^{* *}$} & {$[2]^{* *}$} \\
\hline Elementary & 43.2 & 56.8 & 37.5 & 62.5 & 76.2 & 23.8 & 48.9 & 51.1 \\
\hline Junior high & 29.0 & 71.0 & 50.0 & 50.0 & 71.4 & 28.6 & 47.6 & 52.4 \\
\hline Senior high & 52.4 & 47.6 & 64.0 & 36.0 & 50.0 & 50.0 & 54.6 & 45.4 \\
\hline Academy/University & 61.5 & 38.5 & 60.0 & 40.0 & 50.0 & 50.0 & 55.0 & 45.0 \\
\hline \multirow[t]{3}{*}{ Uneducated } & 50.0 & 50.0 & 66.7 & 33.3 & 0.0 & 100.0 & 50.0 & 50.0 \\
\hline & 44.9 & 55.1 & 50.5 & 49.5 & 60.0 & 40.0 & 51.1 & 48.9 \\
\hline & \multicolumn{2}{|c|}{0.227} & \multicolumn{2}{|c|}{0.345} & \multicolumn{2}{|c|}{0.131} & \multicolumn{2}{|c|}{0.857} \\
\hline
\end{tabular}


Table 6C. Distribution of respondents' answers (in percentage) about the knowledge of symptoms and or signs of epilepsy related to the level of education

\begin{tabular}{|c|c|c|c|c|c|c|c|c|}
\hline \multirow{3}{*}{$\begin{array}{c}\text { Level of education } \\
\text { (school) }\end{array}$} & \multicolumn{6}{|c|}{ The knowledge of the signs and symptoms } & \multirow{2}{*}{\multicolumn{2}{|c|}{ Total }} \\
\hline & \multicolumn{2}{|c|}{ Group I } & \multicolumn{2}{|c|}{ Group II } & \multicolumn{2}{|c|}{ Group III } & & \\
\hline & {$[1]^{* * *}$} & {$[2]^{* * *}$} & {$[1]^{* * *}$} & {$[2]^{* * *}$} & {$[1] * *$} & {$[2]^{* * *}$} & {$[1]^{* * *}$} & {$[2]^{* *}$} \\
\hline Elementary & 62.2 & 37.8 & 37.5 & 62.5 & 95.2 & 4.8 & 77.8 & 22.2 \\
\hline Junior high & 58.1 & 41.9 & 50.0 & 50.0 & 90.5 & 9.5 & 74.4 & 25.6 \\
\hline Senior high & 69.0 & 31.0 & 64.0 & 36.0 & 76.7 & 23.7 & 76.3 & 23.7 \\
\hline Academy/University & 76.9 & 23.1 & 60.0 & 40.0 & 86.4 & 13.6 & 82.5 & 17.5 \\
\hline Uneducated & 25.0 & 75.0 & 66.7 & 33.3 & 100.0 & 0.0 & 62.5 & 37.5 \\
\hline Total & 63.8 & 36.2 & 50.5 & 49.5 & 86.3 & 13.7 & 76.7 & 23.3 \\
\hline $\mathbf{p}$ & \multicolumn{2}{|c|}{0.335} & \multicolumn{2}{|c|}{0.212} & \multicolumn{2}{|c|}{0.374} & \multicolumn{2}{|c|}{0.742} \\
\hline
\end{tabular}

Table 6D. Distribution of respondents' answers (in percentage) about the knowledge of the trigger factors of repeated seizure in epilepsy related to the level of education

\begin{tabular}{|c|c|c|c|c|c|c|c|c|}
\hline \multirow{3}{*}{$\begin{array}{c}\text { Level of education } \\
\text { (school) }\end{array}$} & \multicolumn{6}{|c|}{ The knowledge of the trigger factors } & \multirow{2}{*}{\multicolumn{2}{|c|}{ Total }} \\
\hline & \multicolumn{2}{|c|}{ Group I } & \multicolumn{2}{|c|}{ Group II } & \multicolumn{2}{|c|}{ Group III } & & \\
\hline & {$[1]^{* *}$} & {$[2]^{* *}$} & {$[1]^{* * *}$} & {$[2]^{* *}$} & {$[1]^{* * *}$} & {$[2]^{* *}$} & {$[1]^{* *}$} & {$[2]^{* * *}$} \\
\hline Elementary & 83.3 & 16.7 & 84.4 & 15.6 & 90.5 & 9.5 & 85.6 & 14.4 \\
\hline Junior high & 64.5 & 35.5 & 80.0 & 20.0 & 85.7 & 14.3 & 80.5 & 19.5 \\
\hline Senior high & 78.6 & 21.4 & 88.0 & 12.0 & 66.7 & 33.3 & 77.3 & 22.7 \\
\hline Academy/University & 69.2 & 30.8 & 80.0 & 20.0 & 68.2 & 31.8 & 70.0 & 30.0 \\
\hline Uneducated & 50.0 & 50.0 & 66.7 & 33.3 & 100.0 & 0.0 & 62.5 & 37.5 \\
\hline Total & 75.8 & 25.2 & 87.4 & 12.6 & 76.8 & 23.3 & 79.2 & 20.8 \\
\hline $\mathbf{p}$ & \multicolumn{2}{|c|}{0.271} & \multicolumn{2}{|c|}{0.165} & \multicolumn{2}{|c|}{0.192} & \multicolumn{2}{|c|}{0.207} \\
\hline
\end{tabular}

Note for Table 6A, 6B, 6C, 6D:

Group I : the patients

Group II : the patients' family

Group III: common people

$\begin{array}{ll}{[1]^{*}: \text { Right knowledge }} & {[1]^{* *} \text { : Insufficient knowledge }} \\ {[2]^{*}: \text { Wrong knowledge }} & {[2]^{* *} \text { : Bad knowledge }}\end{array}$

[2]*: Wrong knowledge

[2]**: Bad knowledge

\section{DISCUSSION}

It was noted that there were no studies on the elementary knowledge of epilepsy among the patients, their family or caregiver, and common people in Indonesia.

This study was a grounded survey using the openended questions on the elementary knowledge about epilepsy. For evaluating the answers, the reviewer a priori categorized the respondents' answers based on the right answers compiled from references. Because of the respondents' answers were not equally distributed within the a priori categorizations, then a posteriori categorizations were developed to simplify the data to be analyzed.

\section{Basic characteristics of the respondents}

There were no significant sex differences among the subjects in the three-studied groups $(\mathrm{p}=0.074)$.

Marital status was significantly different among the subjects in the groups $(\mathrm{p}=0.001)$. And it seemed that the marital status correlated to the respondents' age $(p=0.001)$. Sixty three percent of the patients were 
unmarried. Only $30.70 \%$ of the patients were under 19 years old. Based of these numbers, it looked like that $33 \%$ of the patients over 19 years of age have not been married. It could be because of a negative perception on epilepsy.

There was a significant difference on the level of education among the subjects in the three-studied groups $(\mathrm{p}=0.014)$. Only $3.10 \%$ of the patients did not go to school.

About 59\% of the patients were unemployed. Supposed some of them were going to school, it would be consisted of $30.70 \%$ (patients under 19 years of age who were going to the elementary, junior high, and senior high school) plus $10.20 \%$ (who attended to university). A rough calculation would found that $18 \%$ of the patients were really jobless.

\section{Respondents' knowledge of the four aspects of epilepsy in general}

The worst level of knowledge was the knowledge of the main disturbed organ in the body (75.7\%); followed by knowledge about etiology (48.9\%), knowledge about the symptoms and or signs of epilepsy (23.4\%), and the trigger factors of repeated seizure $(20.8 \%)$. It was difficult to explain why the respondents' level of knowledge about the trigger factors and symptoms and or signs of epilepsy were better than their knowledge about etiology and the main disturbed organ in the body. An impression occurred that there were no enough information or education on epilepsy addressed to the respondents, especially on the four aspects of epilepsy.

\section{Respondents' knowledge of the four aspects of epilepsy}

Similar to the general feature, the knowledge by group was worst on the knowledge of the main disturbed organ in the body; followed by knowledge about etiology, knowledge about the symptoms and or signs of epilepsy, and the trigger factors of repeated seizure (Table 5).

It was assumed that the patients would have an intensive communication with their doctors. Surprisingly that the biggest proportion of wrong knowledge about the main disturbed organ was found among the patients (Group I). Compared to the other groups (Group II and III), the Group I (patients) had the biggest proportion of bad knowledge on the etiology, symptoms and or signs of epilepsy, and the trigger factors of repeated seizure. This situation reflected that doctors did not sufficiently educate the patients.

Group II (family of the patients) showed the better knowledge about the main disturbed organ in the body and the trigger factors of repeated seizure, by having the bigger number of the right and insufficient knowledge compared to the other two groups.

Group III (common people) had better knowledge about etiology and symptoms and signs since the group had the biggest proportion of insufficient knowledge category compared to the other two groups.

It was predicted that beside doctors there were many other sources of information on epilepsy.

On the references, there were many misperceptions on epilepsy among common people, i.e.:

- Epilepsy perceived as god's curse and then the patients would be isolated, ${ }^{1}$

- Epilepsy was caused by black magic or ghost ${ }^{1,9}$ and the patients would be isolated and should be treated by traditional healer,

- Epilepsy was a psychological disturbance, ${ }^{10}$

- Epilepsy was a strong hereditary disease, ${ }^{1,11}$

- Epilepsy was a communicable disease. ${ }^{1,11}$

It was interesting that in this study there were no any respondent, which perceived epilepsy as an effect of god's curse, black magic, or other misperception mentioned above.

\section{Relationship between the knowledge of the four aspects of epilepsy and the level of education}

In this study, we found that the level of education did not influence the respondents' level of knowledge of the four aspects of epilepsy. Except the knowledge of the signs and symptom, the knowledge on the other aspects of epilepsy of the patients group was the worst.

\section{Issues behind this research's result}

Mardjono to stated that doctors had a responsibility to educate and to give information about the disease to the patients and their family. ${ }^{1,12}$ In general, the education and information should include the etiology, 
pathophysiology, prognosis, treatment, side effect of the treatment, and risk factors. ${ }^{13}$ There is no specific education program on epilepsy for patients in the Out Patient Clinic of Dr. Kariadi Hospital, where the study had been conducted.

The Epilepsy Association of Scotland had developed a checklist to assist the general practitioners, other doctors, and community teams to meet the information needs of epilepsy patients and their carers. ${ }^{5}$ This checklist would be useful to develop educational or information material to the patients and common people.

The bad level of knowledge on epilepsy among the people (especially the patients) in this study, raises a question: why it was happened. Taylor, noted that patients' level of knowledge about epilepsy was higher than the knowledge of their family and common people. ${ }^{4}$

Regarding to this study, it seems that in the institution where the study was conducted there was no good communication between doctors and patients. The patients' family and common people in this study had better knowledge than the patients, indicated that there were the other sources of knowledge on epilepsy, that have been accessed by the two groups of respondents.

\section{CONCLUSION}

1. The knowledge on the main organ disturbed in epilepsy, etiology, symptoms and signs, and trigger factors for repeated seizure was bad and insufficient among the patients, their family, and common people.

2. There were no significant differences on the level of elementary knowledge about epilepsy among the three groups of respondents.

3. The level of education of the respondents did not influence the level of knowledge.

4. The situation mentioned above reflects:

- a bad and insufficient communication between the doctors and the patients in the health service institution and

- a bad and insufficient public health education on epilepsy, received by the patients' family and common people.

\section{Suggestion}

Since epilepsy is a growing problem in the community, the informations about the elementary knowledge on epilepsy and education of the broader aspects on epilepsy should be addressed to the patients, patients' families, and common people. The information and education should be carried out intensively via medical staff in health service institutions and mass media.

Doctors should spend enough time to give information and to educate patients. Medical staff and the other community members should also increase their effort to use the health service institutions (hospital and community health center), non-governmental institutions, and mass media for providing a campaign against epilepsy. For this purpose, a grand policy at national level, and applied policy at the local level should be developed.

\section{Acknowledgement}

The author gratitude Dr. Susetyo Pramono Hadi, Resident of Department of Neurology School of Medicine Diponegoro University, for his assistance in collecting references and interviewing the respondents.

\section{REFERENCES}

1. Mardjono M. Policy against epilepsy in Indonesia) (Kebijaksanaan penanggulangan epilepsi di Indonesia). Symposium "New breakthrough in the management of epilepsy". Annual scientific meeting and workshop of The Indonesian Neurological Association. Malang, 1998.

2. Study Group on Epilepsy - The Indonesian Neurological Association. Consensus against epilepsy (Konsensus penanggulangan epilepsy Perhimpunan Dokter Spesialis Saraf Indonesia). Jakarta, September 1999.

3. Mc Lin WM, de Broer HM. Public perception about epilepsy. Editorial. Epilepsy 1995; 36 (10): 957-9.

4. Taylor MP. Managing epilepsy in primary care. Oxford: Blackwell Science; 1996. pp 1-10.

5. Gumnit RJ. The epilepsy handbook the practical management of seizures. $2^{\text {nd }}$ ed. New York: Raven Press; 1995.p.104-11.

6. Gumnit RJ. The epilepsy handbook the practical management of seizures. $2^{\text {nd }}$ ed. New York: Raven Press; 1995.p.23-47.

7. Gumnit RJ. The epilepsy handbook the practical management of seizures. $2^{\text {nd }}$ ed. New York: Raven Press; 1995.p.114-23.

8. Buchanan N. What is epilepsy. Epilepsy questions and answers. Sydney: McLennan \& Petty; 1990.p.1-3. 
9. Vanzan A, Paladin F. Epilepsy and Persian Culture: an overview. Epilepsia. 1992; 33 (6): 1057-64.

10. Wiguna T. Interictal psychotic disturbance in frontal lobe epilepsy. (Gangguan Psikotik interiktal pada epilepsi lobus temporalis). Indonesian Psychiatry Quarterly. Jiwa Majalah Psikiatri. 1997; 4: 399-406.

11. Noerjanto M. Neuroradiologic examination on epilepsy (Pemeriksaan neuroradiologik dalam epilepsi). In: Hadinoto
S, ed. Epilepsi. Semarang: Badan Penerbit UNDIP; 1993. p.119-26.

12. Mardjono M. Treatment of epilepsy. (Pengobatan epilepsy). Proceeding of Symposium on current management of epilepsy. (Simposium penanggulangan praktis mutakhir epilepsy); 1990 Oct; Jakarta, Indonesia.

13. Santoso B. The importance of patient counseling. Guest editorial. Medical Progress 1994; Suppl: 5-8. 